\title{
ВАЖКИЙ ШЛЯХ ДО ВАРШАВСЬКОГО ДОГОВОРУ 1920 року
}

У статті проаналізовані передумови, причини та процес формування політико-військового союзу УНР і Польської Республіки. З'ясована роль С. Петлюри та Ю. Пілсудського у підготовці Варшавського договору. Охарактеризовано його зміст, значення та реакцію на нього тогочасного українського і польського політикуму.

Ключові слова: УНР, Польща, Росія, С. Петлюра, Ю. Пілсудський, політико-військовий союз, Варшавський договір.

Постановка проблеми та ї̈ актуальність. Звернутися до вказаної теми автора спонукало, крім їі вельми суперечливого тлумачення в українській та польській історіографріях, започаткованих ще сучасниками описуваних подій, також і те, що спадщина драматичного минулого у свідомості українців і поляків та вражаючий список обопільних претензій й образ і сьогодні справляе значний вплив на їхню свідомість, а нинішній стан двосторонніх відносин оплачений такою трагічно високою ціною у минулому столітті, що існуе реальна небезпека відновлення звинувачень [Детальніше про це: 7, с. 68 - 69]. «Минуле відкидає тіні на українсько-польські відносини, майбутне яких невизначене, - слушно підмітив у травні 2017 р. В. Кравченко. Нині ж Київ і Варшава завмерли на роздоріжжі між довгостроковим партнерством і ситуативним співробітництвом. Криза у двосторонніх відносинах, зовнішнім проявом якої стали розбіжності в політиці національної пам'яті у двох країнах, визрівала довго. Вибухнувши, вона створила вакуум. I тільки від українців і поляків залежить, чим заповниться цей простір - киснем чи метаном» [9].

Оскільки український та польський народи об'єктивно зацікавлені в історичному примиренні, а не конфронтації,

Трофимович Володимир Васильович, доктор історичних наук, професор, професор кафедри гуманітарних наук, Національна академія сухопутних військ імені гетьмана Петра Сагайдачного, м. Львів.

(c) Трофимович В. В., 2017 
чого не можна здійснити без взаємного бажання порозумітись і співробітничати, то дослідники обох країн мають повернутися лицем до тих знакових подій і постатей, які єднають, а не розділяють спільноти сусідніх держав. 3 огляду на це, зазначають польські автори наукового видання «Польща - нарис історії», «можна, однак, подивитися на союз Пілсудський - Петлюра як на спробу порозуміння і співпраці «попри все» й задля вищої мети, якою була свобода обох народів. У цьому контексті, можливо, слід повертатися до цих подій як до символу тяглості прагнень до польсько-української співпраці, а водночас важливої вказівки, що спроби порозуміння без визнання повної рівноправності обох сторін були, $е$ і будуть приречені на поразку» $[24$, с. 232].

Аналіз попередніх досліджень. Слід зазначити, що сучасники С. Петлюри та Ю. Пілсудського вкрай неоднозначно сприйняли ініційований обома лідерами військово-політичний союз, звинувачуючи останніх у неприпустимих поступках «історичному ворогу», «раді національних інтересів» тощо. Зокрема, деякі українські автори вказували на «цинічне» використання Ю. Пілсудським важкого становища УНР для здобуття територіальних і політичних поступок, а саму Варшавську угоду називали «однією 3 найбрудніших сторінок у всій сучасній історії [1, с. 63; 21, с. 15; 24, с. 232].

Після краху комуністичного режиму в Польщі, розпаду CPCP i проголошення незалежності України історики обох держав здійснили суттеві кроки до переосмислення зазначених подій. Цікавий науковий доробок в історіографрію проблеми внесли Я. Брузький, М. Вжосек, В. Верстюк, Л. Вищенський, В. Голубко, Б. Гудь, Т. Зарецька, З. Карпусь, Е. Коко, С. Литвин, О. Михайлова, А. Новак, О. Підлуцький, Я. Пісулінський, Р. Потоцький, М. Прушинський, В. Сергійчук, В. Серчик, I. Срібняк, Ю. Терещенко, P. Тимченко, Р. Тожецький та інші автори.

Мета статті - проаналізувати передумови, причини, зміст і завдання започаткованого С. Петлюрою й Ю. Пілсудським Варшавського договору 1920 року, а також реакцію на нього в Україні та Польщі. 
Стратегічною зовнішньополітичною метою УНР у 19191920 рр. було будь-якою ціною відстояти ï незалежність, добитися визнання Республіки на міжнародній арені та сприйняття світовою спільнотою Директорії як законного уряду України. У зв'язку з цим важливе місце посідала нормалізація відносин із Польщею, що, відродивши у листопаді 1918 р. державну незалежність, вступила у збройні конфлікти з метою встановлення та визнання ï західних і східних кордонів із Німеччиною - за Познань і Верхню Сілезію, з Чехословаччиною - за Тешинську Сілезію, із ЗУНР і УНР - за Львів і всю Східну Галичину, з Литвою за Вільнюс, з більшовицькою Росією - за Волинь й Білорусь [21]. Зокрема, вона прагнула включити до свого складу західноукраїнські землі. Для цього тї збройні сили розгорнули наступ на Східну Галичину, внаслідок якого у липні 1919 р. уся територія ЗУНР була ними окупована, а війська останньої змушені були перейти за р. Збруч.

У лютому 1919 р. Головний Отаман Армії УНР Симон Петлюра прибув до Ходорова для участі в перемовинах 3 фрранцузами стосовно розмежування українських і польських вояків по «лінії Бертелемі». Він наполягав на тимчасовій територіальній поступці полякам, що давало шанс визнання Республіки державами Антанти та створювало сприятливі умови для надання останньою допомоги, проте представники ЗУНР не пристали на такі пропозиції. Тому уряди УНР і ПР не змогли тоді порозумітись.

Необхідність нормалізації двосторонніх відносин диктувала і проросійська політика офіщійних Лондона та Парижа. Юзеф Пілсудський, який 11 листопада 1918 р. зосередив у своїх руках усю повноту влади у відродженій Речі Посполитій, глибоко усвідомлюючи реальну загрозу для національної безпеки з боку Росії, планував відсунути останню від кордонів своєї країни, оскільки відродження «едіной і неділімой» ставало «дамокловим мечем» для незалежної Польщі. Виходячи з цього, Начальник Польської держави заявив, що існування самостійної України відповідало польським інтересам, оскільки остання могла б становити 
«буфер» між Другою Річчю Посполитою та Росією [11, с. 414; детальніше про це див.: 36, s. 79-125]. «Без огляду на те, яким буде їхній уряд, Росія е вперто імперіалістичною, стверджував він. - Це навіть е головною рисою їі політичного характеру... Атака на Польщу залежить, передусім, від українського питання... Якщо українська справа буде вирішеною на їхню користь, тоді вона піде на Польщу» [Цит. за: 41, s. 53].

Перспективи України Ю. Пілсудський бачив не у складі Росії чи Польщі, а як союзника останньої, а тому військові операції поляків на Волині проти армії УНР здійснювалися не з метою ï цілковитого розгрому та знищення державності, як це відбувалось у Східній Галичині, а лише досягнення вигідного для Речі Посполитої кордону та примушування Головного Отамана відступитися від злуки з ЗУНР, що і було реалізовано [17, с. 39]. Позитивно сприймаючи існування УНР, він мав на меті забезпечення польських інтересів. «У ставленні до України Пілсудський керувався передусім національними інтересами своєї країни, зазначив О. Павлюк. - Його розуміння цих інтересів передбачало послаблення Росії, від якої, на його погляд, походила головна небезпека існуванню польської державності» $[16$, с. 7]. 3 огляду на це, польський керманич виношував ідею про федеративний союз з Литвою і Білоруссю та військове співробітництво з УНР. Для останньої це давало шанс зберегти незалежність, але для цього слід було відмовитись на користь Польщі від Східної Галичини і Західної Волині, що на той час вже контролювались ії військами. Своєю чергою, Голова Директорії, вважаючи тоді, що Українська держава може вистояти, лише спираючись на береги Дніпра, дав згоду на територіальні поступки [1, с. 62].

Характерно, що, інтерпретуючи тогочасні погляди Ю. Пілсудського, його особистий секретар К. Світальський записав у своєму щоденнику наприкінці 1919 р.: «Не слід принципово протиставляти анексіоністську та федералістську концепщії, одна не виключае іншої, справа лише у можливості поставити федералістське рішення попереду, щоби 
на випадок, коли їі не вдасться реалізувати, залишався другий вихід [40, s. 40].

Зрештою, як випливає із щоденника генерала А. Лістовського, який, будучи соратником Ю. Пілсудського, відразу після розмов з останнім записував його думки, польський лідер восени 1919 р. ще не зайняв однозначної позиції в українському питанні. Так, 3 листопада він висловив такі міркування: «Час іще не надійшов... нічого не відомо, що нас чекає з Росією, Україною, обома цими державами... Волинський фрронт припинить своє існування, мусимо стояти на лінії угоди з українцями, далі ані кроку... Наближається зима. Тільки весна покаже, що робити далі... Економічне становище Польщі катастрофічне. Ми - сільська країна, але хлібом не тільки не забезпечуємо себе, а ще й потребуємо... отож свою увагу ми повинні зосередити на торгівлі з руських земель... Україна - це економічна та матеріальна праця» [Цит. за:6, с. 2; 37, s. 33].

Із 1919 р. розпочинається налагодження контактів між урядами УНР і ПР [Детальніше про це див.: 5, с. 80 - 84]. Так, В. Прокопович, один з керівників української дипломатичної місії, направленої до Варшави на початку року, після зустрічі з Ю. Пілсудським повідомляв у своє міністерство закордонних справ: «Нова ініціатива встановити нормальні відносини зустріла з боку польських миродатних чинників співчуття. Підгрунтя для переговорів є» [26, с. 149 - 150].

У травні Начальник Польської держави звернувся до Голови Директорії УНР з пропозицією встановити особисті контакти через свою повірену особу - майора «Заглобу» Яна Мазуркевича, аби той запросив С. Петлюру до Варшави 3 метою проведення переговорів. Зустрівшись з останнім, польський представник, який, до речі, добре знав українську мову, переказав йому, що Ю. Пілсудський симпатизує УНР, хоче рівноправного союзу з нею за умови, що Східна Галичина, Західна Волинь, Холмщина, Полісся та Підляшшя мають відійти до Другої Речі Посполитої [5, с. 81 - 82].

Своєю чергою, Голова Директорії та Головний Отаман направив до польської столиці дипломатичну делегацію 
та військову місію з метою укладення військового перемир`я. У переданому для Ю. Пілсудського листі він зазначив, що український народ «у своїй боротьбі з ворогом людської культури і своєї нащіональної державности має право на співчуття та допомогу від своїх найближчих сусідів, тим більше, що відбиваючи свою рідну землю від насильниківокупантів, нав'язуючих Україні чужі їй форми комуністичного ладу, ми не стаєм на шлях білого терору, а йдемо під гаслом широкого демократизму та державного будівництва, найкращим представником якого в Польщі вважаємо ми Вас, Пане Начальнику Держави Польської. Але боротьби з большевиками ми ще не закінчили... Отже, стає очевидною конечність певного порозуміння між польським та українським командуваннями для дальшої боротьби...» [19, с. 358].

У тогочасних умовах Польська Республіка була, на думку С. Литвина, майже єдиною державою, защікавленою у продовженні визвольної боротьби українського народу, і не виключала можливості надати йому військову допомогу. Тому, насамперед, український очільник сподівався порозумітися з нею, а потім і з Антантою. ПР, що користувалася підтримкою останньої й у розпорядженні якої перебувала майже 130-тисячна армія, бачилася надійним союзником для України [10, с. 254].

Варто також наголосити, що для С. Петлюри головну небезпеку становила не Польща Ю. Пілсудського, а Росія В. Леніна. Адже конфлікт з першою, як зауважив О. Підлуцький, носив винятково територіальний характер: поляки намагалися приєднати до своєї країни великі території зі змішаним польсько-українським населенням і українською більшістю, проте переважна їх частина не лише не заперечувала право своїх сусідів на створення власної держави, а й заохочувала таку ідею. Цим вони принципово відрізнялися від Лондона й Парижа, що виступали за відновлення «великої» Росії. «Так само, як білогвардійці, - підкреслив він, - російські більшовики категорично не бажали створення незалежної Української держави. Попри димову 
завісу ленінських декларацій «про право нащій на самовизначення аж до відокремлення», Радянська Росія робила все можливе, щоб силою утримати під своєю владою Україну, хай і надавши їй якусь автономію. Відтак у конфлікті з Росією як білою, так і червоною, жодні компроміси для українських самостійників були неможливі: незалежна держава або ж є, або їі немає» [22, с. 15].

У ході надзвичайно важких боїв унрівських військ з істотно переважаючими частинами Червоної Армії у червні 1919 р. у Львові стартували польсько-українські мирні переговори, що з перервами продовжувались у різних містах, i які були надзвичайно складними та виснажливими. Паралельно направлений Ю. Пілсудським до Головного Отамана у Кам'янець-Подільський полковник Закшевський (Клим Павлюк) мав доручення передати, що польський лідер «стоїть за Україну і дасть дві дивізї, якщо Петлюра про це попросить» [Цит. за: 14, с. 309].

Урешті-решт 1 вересня 1919 р. тогочасний Міністр закордонних справ УНР А. Лівицький домовився в польській столиці про перемир`я між двома арміями, хоча рішуче заперечував вимогу офіщійної Варшави визнати Східну Галичину складовою частиною Польщі. Правда, перемир я не привело відразу до безпосередньої бойової взаємодії українців і поляків, чого добивався С. Петлюра. Як випливало з таємної інструкції Головного командування Польської армї̈ командувачам Волинського та Галицького фрронтів про ставлення до Голови Директорії від 25 серпня 1919 р., до завершення з останнім переговорів, які не гарантують Польщі «політичних компенсацій», не потрібно надавати УНР дієвої допомоги [34, s. 260]. Крім того, стримана позиція Великобританї та Франщії стосовно Директорії УНР не спонукала Начальника Польської держави до прийняття оперативних рішень.

За словами польського автора В. Сулеї, сам Ю. Пілсудський виходив з того, що військова допомога УНР може бути надана лише у той час, коли керівництво останньої повністю усвідомить, що ії подальше політичне існування залежатиме 
винятково від Польщі [38, s. 207]. Розмірковуючи над можливими наслідками такої тактики господаря Бельведеру, Головний Отаман зазначив у листі до очільника дипломатичної місії УНР у Польщі А. Лівицького 11 листопада 1919 р.: «Я не знаю, чи рахуються у Польщі з перспективами завтрашнього дня, чи тільки використовують Status quo. Коли Ви маєте діло тільки з останнім, то це для нас зле, i кінчиться для Польщі теж недобре, хоч і не зараз. Може статись така ситуація, що большовики стануть панами цієї ситуації, і тут ніяка Антанта вдіяти нічого не зможе» [20, c. 140].

На початку осені становище УНР надзвичайно погіршилось: їі збройні сили й уряд опинились у «трикутнику смерті», оскільки в межах однієї губернї на Поділлі вони були оточені більшовицькими військами на північному сході, білогвардійцями - на південному, польськими - на заході [22, с. 15]. Сюди слід додати і перехід Української Галицької Армї на бік генерала Денікіна. Усе це змусило керівників УНР, яким Варшава обіцяла сприяння в реорганізації збройних сил і сформування спільного антибільшовицького фрронту, заявити про незацікавленість Східною Галичиною та частиною Волині [3, с. 23]. «Ми напружуємо всі сили, але чи вистачить їх, я не певен, - писав С. Петлюра 11 листопада у вищевказаному листі до А. Лівицького. 5000 пар чобіт і шинелей, 5000 рушнищь 3 набоями нас могли би врятувати! В цей час полагодження наших стосунків 3 Польщею могло би нас врятувати, - дати нам базу деяку, зносини з світом і перспективи. Дуже жалко, що ми щих переговорів не почали раніш: може б, мали більш сприяючі для нас обставини для заключення договору з Польщею» [20, с. 140].

Звертаємо увагу на те, що і заключення перемир `, і подальше поступове зближення з УНР, яка впритул підійшла до цілковитої катастрофи, вказували на одне: офіщійна Варшава врешті-решт усвідомила небезпеку, яку для неї несла ймовірна поразка ціеї сусідньої країни. «Це значило, підкреслили Б. Гудь і В. Голубко, - що більшовицька Росія 
дістала б можливість впритул наблизити свою достатньо сильну армію до східного польського кордону. Таким чином створювалась ситуація, вельми сприятлива для безпосереднього вторгнення більшовиків у Східну Галичину або ж для укладення ними військової конвенції 3 керівництвом ЗОУНР проти Польщі. Не підлягає сумніву, що і перший, і другий варіант розвитку подій означав реальну небезпеку прориву Червоної армії до Угорщини, де встановився пробільшовицький режим Бели Куна, а звідти - через Баварську радянську республіку у Західну Свропу. Водночас весь тягар протидії експансії московського більшовизму лягав на плечі II Речі Посполитої» [3, с. 16].

Виступаючи у грудні 1919 р. на таємній нараді , на якій були присутні начальник Генштабу С. Галлер і заступник Міністра закордонних справ В. Скшинський, Ю. Пілсудський заявив: «Більшовиків необхідно побити і швидко, доки вони ще не зміцнили свої сили. Треба розправитися з ними так, щоб вони це пам ятали. Для здійснення цього необхідно знайти їх найболючіше місце, щоб вони не змогли учинити належний опір, ухилитися та втекти. Москва не є таким місцем. Київ, Україна їх вразливий пункт...»[Цит. за: 25, с. 10].

Тим часом у польській столищі восени 1919 р. продовжувалися складні двосторонні переговори. «У Варшаві зразу вияснилося, - згадував заступник голови місї УНР, активний діяч ЗУНР С. Витвицький, - що Польщі йшло, в першу чергу про те, щоб, погодившись на польську окупацію, ми зреклися наших прав до Галичини. Почалися переговори тільки з участю членів місії уряду УНР, які старались також спонукати нас до згоди з їхнім становищем. На нас ішов тиск з різних сторін, навіть зі сторони декого з галичан, щоб ми поступились із своїх позищій. Нас старалися переконати, що жодна новоповстала держава не може відразу заволодіти усією своєю територією, що Польща допоможе нам у нашому державному будівництві, а там ми вже відберемо від неї Галичину і т.п. Подібні голоси приходили до нас також з краю... однак ми свого становища не змінили, бо вважали, що це справа принципова» [2, с. 109]. 
В умовах поразки унрівських військ на фронтах, захоплення більшовиками майже всіеї України польська сторона на переговорах займала дедалі твердішу позицію у своїх вимогах, насамперед, територіальних. Усвідомлюючи весь драматизм ситуації, С. Петлюра у листі до голови Надзвичайної дипломатичної місї̈ УНР А. Лівицького від 30 жовтня 1919 р. наполягав: «Тим часом загальний стан нашої Республіки вимагає якнайскорішого полагодження польсько-українських відносин і забезпечення неможливосты альянсу поміж Польщею та «Росією Денікіна» [20, с. 134]. Водночас він рекомендував добиватися повернення українських полонених, «вороту нам військового i санітарного майна та іншого захопленого поляками під час офензиви - оскільки це можливо - з огляду на обставини», придбання амуніції «для нас має величезне значіння», укладання торговельної угоди, неухильного дотримання поляками встановленої по р. Збруч демаркаційної лінії тощо [20, с. 132-133].

Наслідком вищевказаних переговорів стала підготовлена українською стороною 2 грудня Декларація стосовно заключення політичного та військового союзів з Польською Республікою. У ній були окреслені зобов язання УНР і вказувались їі західні кордони. Вона відразу була прийнята польською делегацією.

Попри вимушену відмову від Східної Галичини та Західної Волині, прийнята обома сторонами Декларація була успіхом української дипломатії, оскільки вона домоглася офіційного визнання з боку Польщі, що була в антантівській коаліції, а також одержала від уряду цієї країни обіцянку військової допомоги у протиборстві з Росією [3, с. 24]. Завдяки їй українська сторона: узгодила місце для відходу частини унрівських військ на територію, зайняту збройними силами Польщі; домовилася про евакуацію урядових установ і базу, на якій приступила до реорганізації власної армії; дістала дозвіл на транзит через територію цієї країни та вирішення інших невідкладних потреб [11, с. 420]. «Ми вважали, що не можемо доводити справу до розриву 3 
поляками, бо наша армія не мала б тоді куди відступати, заявив згодом А. Лівицький. - Отже, перед нашою місією стояла дилема: або зовсім відмовитись від якого-небудь порозуміння з Польщею і тоді рахуватися з тяжкими наслідками для справи, або негайно підписувати Декларацію, щоб виграти час і дати можливість нашій армї зміцнити своє становище на фронті проти Денікіна» [13, с. 195 - 196].

У ході особистої зустрічі у Варшаві 9 грудня С. Петлюра та Ю. Пілсудський детально обговорили стан двосторонніх відносин, план реорганізації армії УНР, більшовицьку загрозу для їхніх країн, однак у подальшому переговори української та польської делегацій були припинені, що пояснювалось як внутрішніми, так і зовнішніми причинами, і лише зусиллями лідера Польщі поновились у березні 1920 р. Слід взяти до уваги, що східній політиці Ю. Пілсудського чинили значний опір нащіонал-демократи на чолі з Р. Дмовським, для яких примирення з Росією було меншим злом, ніж незалежна Україна. Не випадково C. Петлюра у листі, написаному Військовому міністру В. Сальському 31 березня 1920 р., попереджував: «Ніколи не забувайте, що польські політики, як п. Пілсудський, повинні боротись в самій Польщі за ідею нашої державності, бо не всі їі розуміють, не всі їі підтримують, а є такі - і досить впливові ще - що й поборюють цю ідею (вшехполяки, ндеки, etc)» [18, с. 263].

Слід було також рахуватися з позищією Антанти, що підтримувала білогвардійців - «неделімщиків». I тільки коли весною 1920 р. армія генерала Денікіна була розгромлена, країни Антанти дали Варшаві можливість діяти стосовно УНР на власний розсуд [23, с. 45]. До того ж, як випливає зі спогадів польського політика i державного діяча С. Грабського, сам Начальник держави тоді ще остаточно не визначився у ставленні до українського питання. Так, наприкінці березня 1920 р. він сказав: «Даю Вам слово, що не піду на Київ і воювати не буду за українську державу для Петлюри». Проте вже через кілька днів, усупереч попереднім словам, Ю. Пілсудський зробив заяву, що «потрібно більшовицький наступ випередити нашим», а 
тому він вирішив здійснити збройний похід на Київ, аби придбати такого «цінного союзника», як Голова Директоpiї УНР [33, s. 145]. Поновлені у березні 1920 р. двосторонні переговори, на яких обговорювалося питання спільного союзу, спрямованого проти більшовицької Росії, що становила загрозу незалежності України та Польщі, відбувались, однак, у надзвичайно важкій атмосфері через непоступливість делегащій стосовно територіальних проблем. I лише тоді, коли до перемовин приєдналися С. Петлюра та Ю. Пілсудський, які 21 квітня протягом п`яти годин вічна-віч обговорювали дразливі аспекти, вдалося знайти той необхідний компроміс, коли слабший партнер мав піти на більші поступки. Його наслідком стало підписання 22 квітня політичної конвенції про співпрацю між українським i польським урядами, що відома як Варшавський договір [11, с. 422 - 423]. Він був таємним і складався 3 дев яти параграфрів, в яких фіксувалися права України, зобов `зання обох країн, кордони останніх. Польща визнавала «права України на незалежне державне існування», а Директорію за верховну владу УНР. Це її рішення пробивало дипломатичну ізоляцію останньої зі сторони Антанти та близьких до неї держав. Український уряд брав на себе зобов`язання не підтримувати жодних міжнародних договорів, спрямованих проти сусідньої країни. Своєю чергою, ПР теж зобов язувалася не укладати антиукраїнських угод. У договорі були застережені національно-культурні права поляків в Україні й українців у Польщі [4, с. 656 - 657; 31, c. 13 - 14]. Згідно нього, УНР, поступившись на офіщійному рівні, визнавала східний кордон ПР по р. Збруч. Це означало, що в складі Речі Посполитої залишалися Східна Галичина, Західна Волинь, Холмшина, Підляшшя, Полісся, тобто етнічні українські землі.

Важливим додатком до політичного договору стала таємна військова конвенція, підписана 24 квітня. У ній був запрограмований спільний військовий похід української та польської армій на Правобережну Україну з метою звіль-

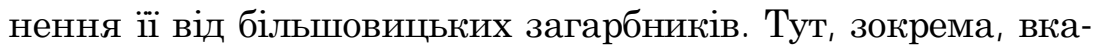
зувалося, що «на польській території буде продовжуватися 
організація українських частин, як - то мало місце до џьго часу в Берестю, аж до часу, коли така організація буде можлива на власній території... Начальна команда Польських військ зобов язується доставити для українських військ зброю, амуніщію, спорядження і одяг в кількості, потрібній для трьох дивізій...» [4, с. 661 - 662; 13, с. 204 - 207; 31, с. 33 - 36]. Водночас, як зауважив Ю. Терещенко, Варшавський договір продемонстрував нерівноправність сторін, а також слабкість позицій УНР, яка була для Польщі союзником без території, могутніх збройних сил і суттевої підтримки українського селянства. Щодо військової конвенції, то згідно з нею планувалося створення лише трьох українських дивізій (15 тис. осіб), тоді як армія партнера налічувала 100 тис. Офщійна Варшава не була зацікавлена у міцному українському війську, оскільки останне здатне було б відіграти роль впливового політичного чинника у двосторонніх відносинах й істотно зміцнити позиції УНР. Вона воліла бачити у ньому допоміжні частини, яким відводилася роль політичного прикриття походу польської армії на Правобережну Україну [27, с. 134].

Потрібно зазначити, що тогочасні державні і політичні діячі, дипломати по-різному оцінювали Варшавський договір. Так, перший Міністр закордонних справ УНР О.Шульгін охарактеризував його наступним чином: Ще було цілою революцією в тодішній нашій закордонній політищі, і треба було великої громадської мужності, щоб по неї зважитись, Симон Петлюра цю мужність мав, але нелегко і йому було зважитись» [32, с. 105]. Разом 3 тим, більшість із них, включаючи М. Грушевського і Є. Петрушевича, піддали Голову Директорії нищівній критищі, називаючи його «авантюристом і українським зрадником», а сам договір - 〈неправним», 〈помилковим», 〈продажом» Галичини Польщі, злочином, який Україна «вже оплатила його своїми інтересами, великими бідами, кров ю, життям і долею синів свого народу та територією» [10, с. 254 - 255; 13, с. 19; 31, с. 4]. А для видання галичан «Український прапор», яке виходило в австрійській столиці, у підписанні угоди було «небувале й неприродне те, щоб якийсь народ, починаючи 
своє державне життя, мусів лишати «ва бортом» найсвідомішу частину своєї землі, зрікатися области, на котрій населення національно найбільш розвинене» [29].

У переважній більшості галицький політикум вважав, що Варшавський договір звів нанівець сенс Акта Злуки УНР і ЗУНР, а петлюрівці спаплюжили і зрадили ідею соборності.

На думку ж самого С. Петлюри, «Варшавська умова 22 квітня 1920 р. була історично вимушеним фрактом, неминучим ланцюгом в ході політично-мілітарних подій нашої новітньої історії...» [19, с. 390]. Він рекомендував розглядати їі «як тактичний хід для встановлення зв язку з Свропою, незалежно од того, що цей акт був актом спасіння для дальшого провадження нашої боротьби» [19, с. 517]. Для нього це був «тимчасовий вихід із тяжкої ситуації. Треба нам якось зміцнити свої сили для того, щоб продовжувати боротьбу з нашим головним ворогом - Московщиною» [13, c. 20]. Відкидаючи численні звинувачення на свою адресу в нерозумінні «справжніх намірів» Польщі, С. Петлюра 1 травня 1920 р. відверто заявив головноуповноваженому уряду УНР у Кам`янці-Подільському І. Огієнку: «Чи думаєте, що я сліпий і нічого не бачу? Але ж пригляньтеся лишень до всього џього уважніше: чи маємо який інший вихід із сліпого закоулка, куди загнала нас зла доля? Чи ми самотужки при нашім розбитті та безсиллі справду зможемо що зробити? Чи ви самі добре не знаєте, що з поляками треба бути або приятелями, або ворогами, нейтральними з ними не можна бути. Я вибрав першу конечність, бо на другу в нас нічого нема...» $[15$, с. 52].

Підписання Варшавського договору мало важливе значення і для Ю. Пілсудського. «Я поставив на карту останню можливість зробити щось на користь майбутнього Польщі, чим послабити могутність Росії у майбутньому, - заявив він 5 травня 1920 р. на нараді армійського штабу. - I коли вдасться допомогти створенню незалежної України, яка буде перепоною між нами і Росією, остання нам багато років не буде загрожувати... Але проблема в тому, чи повстане Україна, чи має вона достатньо сил i людей, щоб організуватися, ми не можемо тут вічно знаходитися і тому 
звертаюся до місцевих поляків, щоб мене зрозуміли і допомогли. Це і в їхніх інтересах, не саботувати, а разом 3 українцями створити державу. Кордонів 1772 року відновлювати не буду, як колись бажав. Польща не потребуе цих земель... Іншого не має - як спробувати створити самостійну Україну» [37, s. 43].

Звідси випливає, що маршал прагнув вибудувати буферну зону між відродженою Польщею і радянською Росією. Він вважав дуже небезпечним опинитись у сусідстві 3 останньою, оскільки таке становище сприяло б більшовизації прикордонних поляків. А коли взяти до уваги, що Східна Галичина - прикордонна територія, переважна частина мешканщів якої були проти включення краю до Другої Речі Посполитої, то такий сценарій уявлявся цілком імовірним $[28$, c. 85$]$.

Ю. Пілсудський, як і С. Петлюра, зазнав жорсткої критики, зокрема, з боку ендеків. Їхній лідер Р. Дмовський звинувачував маршала в тому, що «йому вдалося втягнути державу в шкідливу авантюру» - війну «не заради захисту Польської держави, а задля інтересів чужої держави» [Цит. за: 22 , c. 15].

25 квітня 1920 р. об єднані українсько-польські сили виступили в похід на Київ, який здобули 6 травня. До речі, Ю. Пілсудський того ж дня написав листа С. Петлюрі, в якому зазначив: «Відбувається боротьба за вашу і нашу свободу проти спільного ворога... Я переконаний, що порозуміння між Українською і Польською Республіками, закріплені спільною боротьбою, принесуть славу і довгий добробут обидвом народам» [35, s. 157].

Проте на початку червня Червона Армія розгорнула наступ по всьому фронту, змусивши їх відступити, а 26 липня форсувала р. Збруч. Це означало завершення визвольних змагань УНР і ЗУНР за свою незалежність на власній території і початок нового етапу їх боротьби - тепер уже в еміграції [Детальніше про це див.: 30, с. 4 - 35; 39, s. 113 - 129].

Висновки. Таким чином, розвиток складних, неоднозначних відносин між УНР і ПР у розглядуваний період призвів 
до їх взаємного визнання, підписання на важких для української сторони умовах Варшавського договору, створення нерівноправного політично-мілітарного союзу для збройного опору більшовицькій Росії, що окупувала Україну та загрожувала відродженій Польщі.

На закінчення процитуємо фррагмент листа С. Петлюри до Військового міністра УНР В. Сальського від 31 березня 1920 р., який звучить нині як своєрідний заповіт: «Ми - Польща і Україна - повинні досягти... порозуміння, щоб перед Москвою устояти. Посилання на історію польсько-українських непорозумінь в минулому для сучасного реального політика не є аргумент. Нові відносини вимагають і з боку польського уряду корективів до минулої політики і життевий інтерес Польщі примушує їі мати самостійну Україну [18, c. 263].

В умовах нинішньої агресї Росії проти України, а також враховуючи те, що у новій польській оборонній доктрині РФ визначено як головну загрозу для регіону Східної Свропи, варто прислухатися до цієї вельми актуальної думки.

1. Верстюк В. Союз Ю. Пілсудського - С. Петлюри 1920 р. в сучасній українській історіографії / В. Верстюк // Наукові записки НаУКМА. - 2005. - Т.41. - С. 61 - 65.

2. Витвицький $C$. Галичина в міжнародній політиці в 1914-1923 роках. Спогади / С. Витвицький // Український історик. - 1995. - Ч.30. - С. 100 - 118.

3. Гудь Б., Голубко В. Нелегка дорога до порозуміння: До питання генези українсько-польського військовополітичного співробітництва 1917-1921 pp. / Б. Гудь, В. Голубко. - Львів: Українські технології, 1997. - 66 с.

4. Документы и материалы по истории советско-польских отношений. - М., 1964. - Т.2. - 720 с.

5. Зарецька T. Відносини Директорії Української Народної Республіки з Польською Республікою (19191920 рр.) / Т. Зарецька // Міжнародні зв язки України: наукові пошуки і знахідки. - 2002. - Вип.11. - С. 76-92.

6. Зарецька T. Симон Петлюра і Юзеф Пілсудський. Магістральне місце в історії українсько-польських відносин / Т. Зарецька // Історія України. - 2005. №16. C. 1 - 8. 
7. Зашкільняк Л. Образ Польщі та поляків у сучасній Україні / Л. Зашкільняк // Проблеми слов'янознавства. - 2011. - Вип. 60. - С. 68 - 80.

8. Корольов Г. Союз Ю. Пілсудського - С. Петлюри в контексті геополітичного вибору / Г. Корольов // Проблеми вивчення історії Української революції 19171921 рр. - К., 2010. - Вип.5. - С. 275 - 286.

9. Кравченко В. Україна-Польща: між довгостроковим партнерством і ситуативним співробітництвом / В. Кравченко // Дзеркало Тижня. - 2017. - №17.

10.Литвин С. Симон Петлюра у 1917-1926 роках. Історіографія та джерела: Монографрія / С. Литвин. К.: Аквілон-Прес, 2000. - 464 с.

11. Литвин C. Петлюра і Пілсудський: Нелегкий шлях до порозуміння / С. Литвин // Війни і мир. - К.: АТЗТ «Українська Прес-група», 2004. - С. 412 - 427.

12. Мазепа $I$. Україна в огні й бурі революції 19171921. - Т.2: Кам`янецька доба - Зимовий похід. / I. Мазепа. - Мюнхен: Прометей, 1951. - 245 с.

13. Мазепа I. Україна в огні й бурі революції 19171921. - Т.3: Польсько-український союз. Кінець збройних змагань УНР / І. Мазепа. - Прага: Пробоєм, 1943. - 233 с.

14. Нагаєвський $I$. Історія Української держави двадцятого століття / І. Нагаєвський. - К ., 1994. - 615 с.

15. Огієнко I. Урочистий в Їзд С. Петлюри до Кам`янцяПодільського 1 травня 1920 р. Уривок споминів / I. Огієнко // Наша культура (Варшава). - 1936. - Кн.5. - С. 50 - 52.

16. Павлюк $O$. Українсько-польський союз і політика США щодо УНР у 1920 р. / О. Павлюк // Український історичний журнал. - 2000. - №6. - С. 3-16.

17. Папакін $A$. Стосунки між УНР та Польщею в 1918-1919 pp. / А. Папакін // Наукові записки НаУКМА. - 2004. - Т.27: Історичні науки. - С. 38 - 41.

18. Петлюра С. Статті, листи, документи / С. Петлюра. Нью-Йорк, 1956. - (видання вийшло без позначення «Том 1») - $480 \mathrm{c}$.

19. Петлюра С. Статті, листи, документи / С. Петлюра. Нью-Йорк, 1979. - Т.2. - 627 с.

20. Петлюра С. Статті, листи, документи / С. Петлюра. К.: Вид-во ім. О. Теліги, 1999. - Т.3. - 615 с.

21. Підлуцький $O$. Юзеф Пілсудський: начальник, який створив собі державу / О. Підлуцький // Дзеркало тижня. - 2001 - №5. - С. 15. 
22. Підлуцький $O$. Нереалізований шанс / О. Підлуцький // Дзеркало тижня. - 2010 - №16. - С. 15.

23.Польща та Україна в боротьбі за незалежність 1918-1920. - Варшава: Віпарт, 2010. - 521 с.

24. Польща - нарис історії. - Варшава: Тирса, 2015. $366 \mathrm{c}$.

25. Прушинський $M$. Драма Пілсудського. Війна 1920 р. / М. Прушинський. Пер. з польськ. Булгакова В., Ведіної В. - К.: Лібра, 1997. - 361 с.

26. Стахів М. Україна в добі Директорії УНР. Вихід 3 кризи / М. Стахів. - Нью-Йорк, 1964. - T.VIII. - 431 c.

27. Терещенко Ю. Варшавський договір 1920 р. і його оцінка українською дипломатією / Ю. Терещенко // Симон Петлюра у контексті українських національновизвольних змагань: Збірник наукових праць. - Фастів: Поліфраст, 1999. - С. 130 - 139.

28. Тимченко Р. Варшавська угода: доля Східної Галичини // Український історичний збірник. - 2011. Вип.14. - С. 80 - 88.

29. Український прапор. - Відень. - 1920. - 8 травня.

30.Українсько-московська війна 1920 р. в документах (оперативні документи штабу армії УНР з передмовою і під редакцією генерала В. Сальського. Документи впорядкував генерал П. Шандрук). - Варшава, 1939. - 308 c.

31. Шелухін $C$. Варшавський договір між поляками й С. Петлюрою 21 квітня 1920 року / С. Шелухін. Прага, 1926. - 40 с.

32. Шульгін $O$. Симон Петлюра та українська закордонна політика / О. Шульгін // Збірник пам яті Симона Петлюри (1879-1926). - К.: МП «Фенікс», 1992. C. 172 - 176.

33.Grabski S. Pamiętniki /S. Grabski. - Warszawa: Czytel nik, 1989. - T.2. - $516 \mathrm{~s}$.

34. Nowak $A$. J ak rozbić Rosyjskie imperium? Idee polskiej polityki wschodniej (1733-1921) / A. Nowak. Warszawa: WOW GRYF, 1995. - $376 \mathrm{~s}$.

35. Piłsudski J. Pisma zbiorowe / J. Piłsudski. Warszawa: KAW, 1990. - T.5. - $297 \mathrm{~s}$.

36. Pisuliński J. Nie tylko Petlura. Kwestia ukraińska w polskiej polityce zagranicznej w latach 1918-1923 / J . Pisuliński. - Poznań, 2013. - 480 s.

37. Rok 1920. Rozmowy z J ózefem Piłsudskim Z Dziennika Antoniego Listowskiego (1919-1920). Opracował A. Nowak // Arkana. - 1998. - Nr.23. - S. 30-70. 
38.Suleja W. J ózef Piłsudski / W. Suleja. Wyd.2. Wrocław; Warszawa; Kraków, 1995. - 383 s.

39. Suleja W. Piłsudski a Petlura / W. Suleja // Polska i Ukraina. Sojusz 1920 roku i jego następstwa. - Toruń: Wyd-wo UMK, 1997. - S. 113 - 129.

40. Świtalski K. Diariusz 1919-1935 / K. Świtalski. Warszawa, 1992. - $837 \mathrm{~s}$.

41. Wraga R. Piłsudski a Rosja / R. Wraga // Kultura. 1947. - Nr.2-3. - S. 50 - 65.

Надійшла до редколегії 05.09. 2017 р.

Рецензент: B.C. Голубко, доктор історичних наук, професор, завідувач кафедри історичного краєзнавства, Львівський національний університет імені Івана Франко, м. Львів.

\section{Trofymovych Volodymyr}

\section{THE DIFFICULT WAY TO THE TREATY OF WARSAW 1920}

The article analyzes the preconditions, causes and process of formation of the political-military alliance of UNR and Polish Republic. The role of S. Petliura and J. Pilsudski in the preparation of the Warsaw Pact has been clarified. His content, significance and reaction to him at that time of Ukrainian and Polish political forces were characterized.

Keywords: UNR, Poland, Russia, S. Petliura, J. Pilsudski, PoliticalMilitary Alliance, Treaty of Warsaw. 